\title{
Richard N. Frye
}

1920-2014

RICHARD N. FRYE WAS AN ACADEMIC ADVENTURER. HIS MEMOIR, GREATER IRAN: A $20^{\text {th }}$-Century Odyssey, begins with his OSS years in Afghanistan and dwells far more on flat tires in the desert, washed-out mountain roads, and wretched sleeping accommodations than on the inscription he copied or the ruin he visited at the end of his journeys through remote parts of the Iranian world. It also details his warm acquaintance with hundreds of Iran scholars in a score of countries, along with his remarkable ability to speak with almost all of them in their native languages. The title Irandoost, "Friend of Iran," bestowed on him by Iran's most eminent scholars, was well warranted. At a field station for Iranian archaeology students in 1977 I heard him introduced with just that one word. It was enough.

Frye began and ended his scholarly career at Harvard, but he gave serious thought to relocating to Hamburg or Shiraz. He was not a conscientious teacher, and after serving as jack-of-all-lectures during the fledgling years of Harvard's Center for Middle East Studies, he "retired" from the Center when H.A.R. Gibb, whom he did not harmonize with, became its director in 1955. As Agha Khan Professor of Iranian Studies, Frye thenceforward restricted his Harvard teaching to pre-Islamic Iranian languages and thus had comparatively few students. The Heritage of Persia (1963) reflects his deep learning about Iran's early history and basically contains the lectures that Harvard students never heard him give. That being said, his doctoral work on the history of Bukhara, and later The Golden Age of Persia (1988) about Iran after the Arab conquest, gained a greater readership than his more technical works on the pre-Islamic period.

When the Iranian Revolution limited his opportunities to visit Iran, he renewed his interest in Afghanistan, where his second wife, Eden Naby, had served in the Peace Corps. He also took advantage of the waning of Soviet power to make numerous visits to Central Asia. His book The Heritage of Central Asia (1996) testifies to his conviction that Iran should be conceived of not just as a country bounded by the frontiers of the Islamic Republic of Iran, but as a 
great civilization that at one time spread over a vastly broader area reaching through and beyond Afghanistan and Central Asia.

Frye was a good épée fence, a competent horseman, and a superb raconteur. Well I remember inviting him to tell an informal gathering of graduate students about the countries in which he had been arrested. He held them spellbound. \&

Richard W. Bulliet Columbia University

\section{Pierre Oberling}

1929-2014

PIERRE OBERLING, DISTINGUISHED HISTORIAN, ETHNOLOGIST, AND POET, DIED on 22 March 2014 at his home in Reston, VA following a brief illness. Oberling was born in Strasbourg, Alsace (France) in 1929 to the distinguished French pathologist Charles Oberling and his wife Martha. In his youth he traveled widely with his family throughout Europe and the Middle East. He spent two years in Tehran, Iran, during World War II before immigrating to the United States in 1942. He earned a master's degree in French literature from Cornell University (1951), a master's degree in international affairs (1953), and a $\mathrm{PhD}$ in Middle East languages and cultures (1960) from Columbia University. Following brief stints teaching in Athens and Istanbul, he taught European and Middle Eastern history at Hunter College (City University of New York), from 1963 to 1998. He also served as director and treasurer of the American Research Institute in Turkey, co-editor of Near and Middle East Monographs, and contributing editor to the Encyclopedia Iranica.

Oberling's early research focused on Turkic tribes in Iran, resulting in the publication of The Qashqa $i$ Nomads of Fars (1974). He was an outspoken advocate of human rights and became involved in documenting the political and cultural history of Turkish Northern Cyprus through two seminal works: The Road to Bellapais: The Turkish Cypriot Exodus to Northern Cyprus (1982) and The Heart of a Nation: A History of Turkish Cypriot Culture 1571-2001 (2007). In 2001, Oberling was awarded the Distinguished Service Award of the Ministry of Foreign Affairs, Republic of Turkey, for this work. 